\title{
Prevalence of hepatitis B and hepatitis C infection in Libya: results from a national population based survey
}

Mohamed A Daw ${ }^{1,3^{*}}$, Abdallah El-Bouzedi ${ }^{2}$ and In association with Libyan Study Group of Hepatitis \& HIV

\begin{abstract}
Background: Libya is one of the largest countries in Africa and has the longest coast in the Mediterranean basin facing southern Europe. High rates of prevalence of viral hepatitis have been observed in various regions in Africa, but the prevalence in Libya is not well documented. We report on a large-scale nationwide study that evaluated the epidemiology of hepatitis B and hepatitis C in Libya and assessed the risk factors involved.

Methods: A cross-sectional study was carried out in 2008 on 65,761 individuals all over Libya. The country was divided into 12 regions according to the population density and sampling within each region was carried out under the supervision of the National Centre for Prevention of Infectious Diseases. Serum samples were collected from both males and females of all ages in both urban and rural areas and tested for HBsAg for hepatitis B and anti-HCV antibody for hepatitis C. Prevalence rates were determined in regions and in different groups and correlated with different demographic and risk factors involved in the spread of these viruses.

Results: The prevalence of hepatitis $B$ and hepatitis $C$ viruses varied regionally across the country. The overall prevalence of hepatitis B was $2.2 \%(95 \% \mathrm{Cl} 2.1 \%-2.3 \%)$ and was higher among males than females (1.4:1.0). Hepatitis $\mathrm{C}$ virus (HCV) prevalence was $1.2 \%(95 \% \mathrm{Cl} 1.1-1.3)$ and it increased gradually after the age of 30 years $(0.7-0.9 \%$ for $<30$ years; $3.6 \%$ for $\geq 60$ years). Prevalence of $\mathrm{HBsAg}$ was $0.8-0.9 \%$ below the age of 10 years, and higher but similar in older age groups (2.3-2.7\%). There was an association between literacy and prevalence of hepatitis, particularly for HCV. Hospital admission, surgical operation, blood transfusion, and intravenous drug use were the main risk factors, and they were associated independently with a higher prevalence rate of viral hepatitis.

Conclusions: Libya may be considered an area of low-intermediate endemicity for hepatitis B virus infection, with lower rates in young age groups, and an area of low endemicity for hepatitis $C$. The prevalence of hepatitis $B$ and $C$ across Libya is not homogeneous, with indications of the effect of the higher rates in some neighbouring countries. Libya should adopt full coverage national plans and guidelines to face the future consequences of viral hepatitis, particularly hepatitis $C$ virus.
\end{abstract}

Keywords: Hepatitis B virus, Hepatitis C virus, Libya, Prevalence, HBsAg, Anti-HCV-Ab

\footnotetext{
*Correspondence: mohamedadaw@gmail.com

'Department of Medical Microbiology, Faculty of Medicine, Tripoli, Libya

${ }^{3}$ Professor of Clinical Microbiology \& Microbial Epidemiology, Acting

Physician of Internal Medicine, Scientific Coordinator of Libyan National

Surveillance Studies of Viral hepatitis \& HIV, Tripoli, Libya

Full list of author information is available at the end of the article
} 


\section{Background}

Hepatitis $B$ and $C$ viruses (HBV and HCV) are the major causes of liver diseases in the world. The relative importance of HBV and HCV infections varies greatly from one part of the world to another and changes over time [1]. Worldwide, over two billion people are infected by HBV alone, of whom about one million die annually. Hepatitis $\mathrm{C}$ virus affects about 200 million people [2]. However, in many countries its prevalence is expected to surpass that of hepatitis B, particularly among certain risk groups that are vulnerable to both hepatitis $B$ and $C$ viruses [3].

The endemicity of HBV infection varies greatly over the world, from highly endemic areas ( $>8 \%$ infection rate), to intermediate $(2-8 \%)$ and low endemicity areas $(<2 \%)$. Africa is among the highly endemic areas, but some countries in the north fall in the intermediate category, with an average rate of about $7 \%$, whereas most regions of west and east Africa are highly endemic areas with chronic infection rates of 7-10\% [4]. In some countries, such as Senegal, a large part of the population will be exposed in the course of their lives to HBV and become infected [5]. All of central and southern Africa is also in the high endemicity category [6]. Few studies evaluated the status of HBV in Libya. In 2000, Daw et al. [7] reported a HBV prevalence of $10 \%$ among hospital health-care workers and that infection was associated with certain occupational risk factors.

Hepatitis $\mathrm{C}$ virus infection is a major public health problem [8,9]. African countries have among the highest prevalence rates of $\mathrm{HCV}$ in the world, ranging from 1 to $26 \%$ [10,11]. More than 28 million people are chronically infected with HCV in this continent, and it is difficult to speculate about current and future trends $[3,12]$. In Libya, one study reported that the prevalence of $\mathrm{HCV}$ among different populations varied according to the risk factor involved [13]. Recently, a comprehensive study was carried out on HCV genotypes in Libya. Hepatitis C virus genotype 4 was the predominant one, followed by $\mathrm{HCV}$ genotype 1 and then other less common genotypes [14]. However, further studies are needed to clarify the magnitude and impact of HCV in Libya.

Viral hepatitis has tremendous socioeconomic, healthcare and even political repercussions. A better understanding of the epidemiology of viral hepatitis and the risk factors involved is among the priorities of any nation $[15,16]$. Reliable epidemiological data on prevalence rates and transmission routes $[17,18]$ of viral hepatitis are essential for designing national control policies. The epidemiological data in Africa are scanty and vary greatly from one region to another [4]. Therefore, each country should adopt its own strategy to combat viral hepatitis.

Libya has an area of $1,775,500 \mathrm{~km}^{2}$ and a population reported in mid 2006 as 5,323,991, giving a population density of 2.9 persons per $\mathrm{km}^{2}$. The country boasts the highest literacy and educational enrolment in North
Africa and among the Arab nations [19,20]. Life expectancy (73 years) and health-adjusted life expectancy (64 years) are among the best in the Middle East and North Africa $[19,21]$. Nevertheless, Libyan health services have been hampered by bureaucracy and lack of proper long-term planning $[20,22]$. Both Libyan and international medical experts have voiced concerns about the potential for increases in infection, particularly viral hepatitis and AIDS [23,24].

Recent data on the prevalence of hepatitis B and C viruses and risk factors among the Libyan population are lacking. Such data are important for understanding the burden of viral infection and for predicting future trends. Implementation of surveillance to guide public health policy is needed to efficiently control viral hepatitis spread in this country, and this requires reliable epidemiological data. In this comprehensive nationwide study we determined the prevalence of hepatitis $B$ and $C$ virus infections among the Libyan population and analysed the risk factors.

\section{Methods}

\section{Study population}

We conducted a national cross-sectional study stratified by region and age. The sample size in each region was set ahead of the survey and recruitment continued until the sampling teams fulfilled the required sample size. Those enrolled from each region were selected randomly. Regional representativeness was fulfilled by classifying the country into 12 regions including all administrative divisions and sampling based on population proportions. Sample sizes of males, females and age strata were determined by multi-stage cluster sampling in each region proportional to regional populations according to the latest national census in 2003-2004. Teams of medical doctors and nurses established the sampling frames and collected the information and samples in all the regions as described in Table 1. The following targeted age strata were selected:

$-<6$ years: Pre-school children (maternal and child care centres);

- 7-19 years: School age below university level (primary, preparatory and high schools);

- 20-49 years: University graduate and post graduate students (universities and health services centres);

$-\geq 50$ years: Employed and retired personnel (different community and governmental sectors).

\section{Demographic and epidemiological data questionnaire}

Sample size calculations were based on the prevalence of $\mathrm{HCV}$ and HBV infections in prior studies in Libya. To detect a two-fold increase in prevalence among the lowest prevalence expected for HCV 1/1000 in each age group as compared with the next age, a sample of 25,476 has a power of $80 \%$ (beta error $<0.2$ ) to detect this difference at the alpha $=0.05$ level (one-sided). A 
Table 1 Numbers of samples collected from the 12 Libyan regions

\begin{tabular}{llll}
\hline Region & Number & Percent & Ratio* $^{*}$ \\
\hline Albatnan & 4996 & 7.6 & 1.80 \\
Aljabal Alakhdar & 5944 & 9.0 & 1.10 \\
Benghazi & 6938 & 10.6 & 1.10 \\
Ajdabia & 4963 & 7.5 & 1.10 \\
Sirt & 3871 & 5.9 & 1.75 \\
Misrata & 4966 & 7.6 & 1.90 \\
Almergeb & 4913 & 7.5 & 1.10 \\
Tarhuna & 5023 & 7.6 & 1.10 \\
Tripoli & 8013 & 12.2 & 1.10 \\
Alzawia & 5022 & 7.6 & 1.80 \\
West mountain & 5752 & 8.7 & 1.10 \\
Fezzan & 5360 & 8.2 & 1.90 \\
Total sample & 65761 & 100 & 1.10 \\
\hline
\end{tabular}

*Ratio of individuals testing positive for hepatitis $B$ and $C$ viruses to the total population in each region. total sample of 51,000 would allow estimation of these parameters independently for males and females.

Individuals confirmed to be infected with $\mathrm{HCV}$ were referred to the main teaching hospitals in the major regions: Tripoli Central Hospital and Tripoli Medical Centre for western and central regions, Benghazi Medical Centre for the eastern regions, and Sebha Medical Centre for Fezzan area. These hospitals receive all individuals who test positive for anti-HCV, HBV or HIV from all over the country as a policy run under the control of the Libyan National Health Authority.

The questionnaire sought information about age, gender, education, residence and occupation, as well as history of major invasive interventions, use of recreational intravenous drugs, and promiscuous sexual practices. The questionnaire was completed by each participant and those of a younger age were helped by their parents in the presence of medical doctors and social assistants, who recorded the needed information and coded the questionnaire.

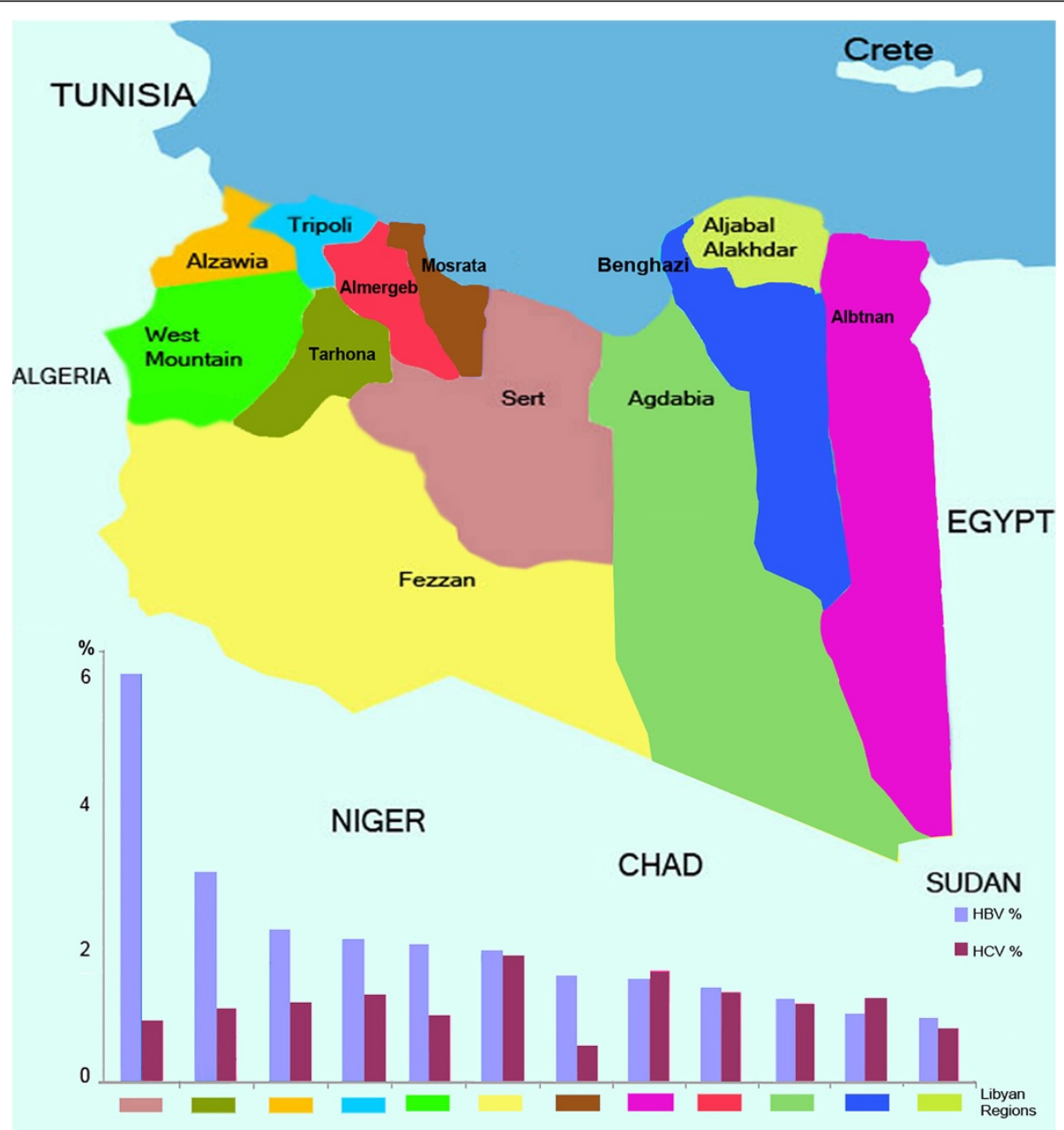

Figure 1 Map of Libya showing the prevalence of hepatitis B and C infections by region. 


\section{Laboratory tests}

A blood sample of 5-10 $\mathrm{ml}$ was collected and transported immediately to the local laboratory in a general hospital within the same region. Serum was prepared and stored at $-20^{\circ} \mathrm{C}$ until tested as previously described [14].

All samples were tested for $\mathrm{HBsAg}$ and anti-HCV markers by using a third-generation enzyme immunoassay (Axsym; HCV EIA 3.0; Abbott Laboratories, Abbott Park, Illinois, and HBsAg, Axsym) as previously published [14]. Samples that were positive for anti-HCV were retested by the same method, and only if the retest was positive were they considered as positive.

\section{Statistical analysis}

Data were coded and entered into a data base, which was then cleaned and verified. Data were analysed by using the Chi-square test with Yates' correction or Student's $t$-test for univariate analysis. Multivariate analysis was performed by using logistic regression, with antiHCV serologic results as the dependent variable (SPSS, Inc., Chicago, Illinois). Prevalence estimates are reported with $95 \%$ confidence intervals $(\mathrm{CI})$ determined by using the Poisson distribution approximation [18]. A type I error of $\alpha=0.05$ was assumed. Sample weighting was later performed and a weight was calculated according to age and sex within each region.

\section{Ethical considerations}

The study was approved by the Libyan National Ethical Committee (Approval No. LY NS; HV299789). It was conducted in accordance with the Helsinki Declaration [25] and under the supervision of the Libyan Centre for Disease Control. All participants signed an informed consent form witnessed by the local health office before collection of data and blood samples. The questionnaire used to collect demographic and epidemiological data (Additional file 1: Table S1) was anonymous and linked to the blood sample tube only by a code.

\section{Results}

The overall prevalence of HBsAg positivity was 2.2\% (95\% CI 2.1\%-2.3\%). The prevalence varied from one region to another (Figure 1). The rate was highest in Sirt (6.6\%) and Tarhuna (3.4\%), and lowest in Aljabel Alakhdar (1.0\%), Benghazi (1.0\%), and Ajdabia (1.4\%). The overall prevalence of $\mathrm{HCV}$ was $1.2 \%$ but it varied from one region to another (Figure 1). The highest rates were in Fezzan (2.2\%) and Albatnan (1.8\%) and the lowest were in Misrata (0.6\%), Sirt (1.0\%) and Western Mountain (1.1\%). The rate of HBV prevalence was significantly higher in males (2.6\%; 95\% CI 2.4-2.7) than in females $(1.8 \%$; 95\% CI 1.6-1.9). The probability of being HBsAg positive was 1.4 times higher among males than females.

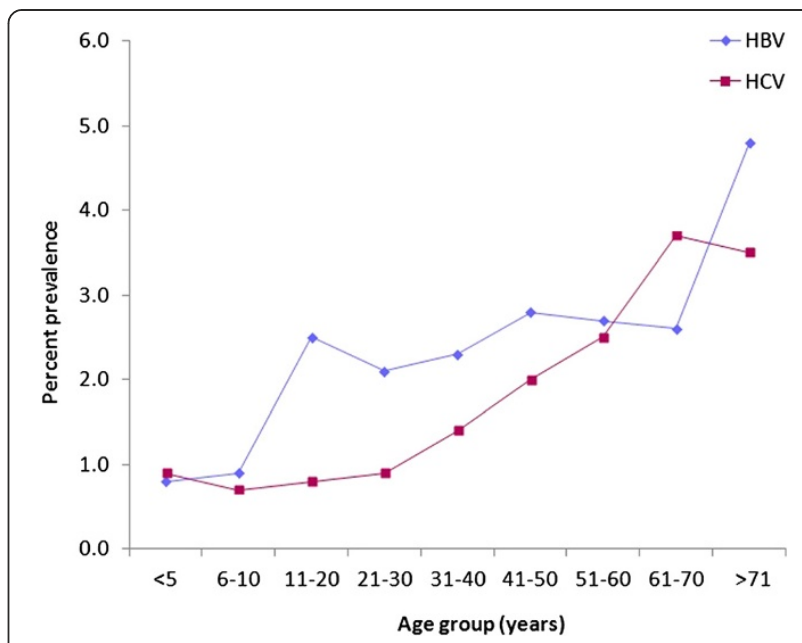

Figure 2 Prevalence of hepatitis B and C infections by age, Libya, 2008.

The overall unweighted prevalence of $\mathrm{HCV}$ was $1.2 \%$ (95\% CI 1.1-1.3), and it rose to $1.3 \%$ after weighting. For those aged $>20$ years, the unweighted and weighted percentages were not significantly different $(1.5 \%$ and $1.6 \%$, respectively). The prevalence rate was slightly higher

Table 2 Association between hepatitis B and C virus infections and influencing factors among the Libyan population

\begin{tabular}{|c|c|c|c|c|c|c|}
\hline & \multicolumn{3}{|c|}{$\mathrm{HCV}$} & \multicolumn{3}{|c|}{ HBsAg } \\
\hline & \multirow[t]{2}{*}{ OR } & \multicolumn{2}{|c|}{ 95.0\% C.I. } & \multirow[t]{2}{*}{ OR } & \multicolumn{2}{|c|}{ 95.0\% C.I. } \\
\hline & & Lower & Upper & & Lower & Upper \\
\hline \multicolumn{7}{|c|}{ Age group (years) relative to $<6$} \\
\hline $6-10$ & 0.74 & 0.46 & 1.18 & 1.21 & 0.79 & 1.86 \\
\hline $11-20$ & 0.91 & 0.67 & 1.24 & 3.36 & 2.5 & 4.52 \\
\hline $21-30$ & 0.88 & 0.63 & 1.22 & 3.01 & 2.21 & 4.1 \\
\hline $31-40$ & 1.41 & 1.01 & 1.96 & 3.14 & 2.28 & 4.32 \\
\hline $41-50$ & 1.87 & 1.32 & 2.64 & 3.77 & 2.7 & 5.26 \\
\hline $51-60$ & 2.36 & 1.65 & 3.37 & 3.7 & 2.59 & 5.28 \\
\hline $61-70$ & 3.27 & 2.17 & 4.93 & 3.34 & 2.13 & 5.24 \\
\hline$>70$ & 3.32 & 2.01 & 5.49 & 5.69 & 3.54 & 9.15 \\
\hline Males vs females & 0.86 & 0.74 & 0.99 & 1.51 & 1.35 & 1.68 \\
\hline Hospital admission & 1.32 & 1.09 & 1.61 & & & \\
\hline Dental procedure & 0.84 & 0.71 & 0.99 & 0.85 & 0.76 & 0.96 \\
\hline Blood transfusion & 1.55 & 1.22 & 1.97 & & & \\
\hline Intravenous drug use & 6.41 & 2.27 & 18.07 & 0 & 0 & - \\
\hline Surgery & 1.35 & 1.08 & 1.67 & & & \\
\hline Family HBV & 1.52 & 1 & 2.3 & 1.97 & 1.46 & 2.64 \\
\hline Haemodialysis & 4.37 & 1.71 & 11.2 & & & \\
\hline Contact with HBV & & & & 1.66 & 1.23 & 2.23 \\
\hline Skin piercing & & & & 1.36 & 1 & 1.83 \\
\hline
\end{tabular}


among females than males but the difference was not statistically significant. The prevalence rates weighted for other factors (age group, education, marital status, type of dwelling, and risk exposure) are shown in Additional file 2: Table S2.

Figure 2 shows the prevalence of $\mathrm{HBV}$ and $\mathrm{HCV}$ among the Libyan population according to age. The prevalence of anti-HCV was stable at $0.8-0.9 \%$ until the age of 30 years, after which it rose steadily, reaching $2.7 \%$ in those above the age of 50 years. In contrast, the prevalence of HBsAg was lowest in the youngest age group ( $0.9 \%)$, and in the older groups it fluctuated between $2.0 \%$ and $2.9 \%$ without any evident temporal trend. However, it rose sharply after the age of 70 years.

The overall prevalence rates of $\mathrm{HCV}$ in males and females were similar (1.1\% and $1.3 \%$, respectively). The mean ages of anti-HCV positive females ( $31.7 \pm 18.4$ years) and males $(35.6+20.9$ years $)$ were significantly higher $(\mathrm{p}<0.001)$ than those of HBsAg positive females $(26.3+$ 16.8 years $)$ and males $(30.0+17.6$ years). The mean age of
HCV positive individuals was significantly higher than that of anti-HCV negative individuals for both males (almost 10 years difference) and females (7 years difference). The mean age of HBsAg positive individuals was also significantly higher (but to a lesser degree) among females (by $<2$ years) and males (by $<4$ years). More than $50 \%$ of the $\mathrm{HBsAg}$ positive individuals and about $40 \%$ of $\mathrm{HCV}$ positive cases were below 30 years of age.

The associations between hepatitis $\mathrm{B}$ and $\mathrm{C}$ virus infections and various factors are shown in Table 2. Hepatitis B virus was more prevalent among the illiterate group (2.9\%) than among the literate groups: $1.6 \%$ among postgraduates and $2.3 \%$ among preparatory school students. The prevalence of HCV was also higher among the illiterate group $(3.1 \%)$ whereas in the literate groups it ranged from $0.9 \%$ to $1.1 \%$. The influence of marital status and living standard on the prevalence of hepatitis B and C is shown in Figure 3. Hepatitis B was more prevalent among the widowed, whereas $\mathrm{HCV}$ was more prevalent among single and younger individuals.

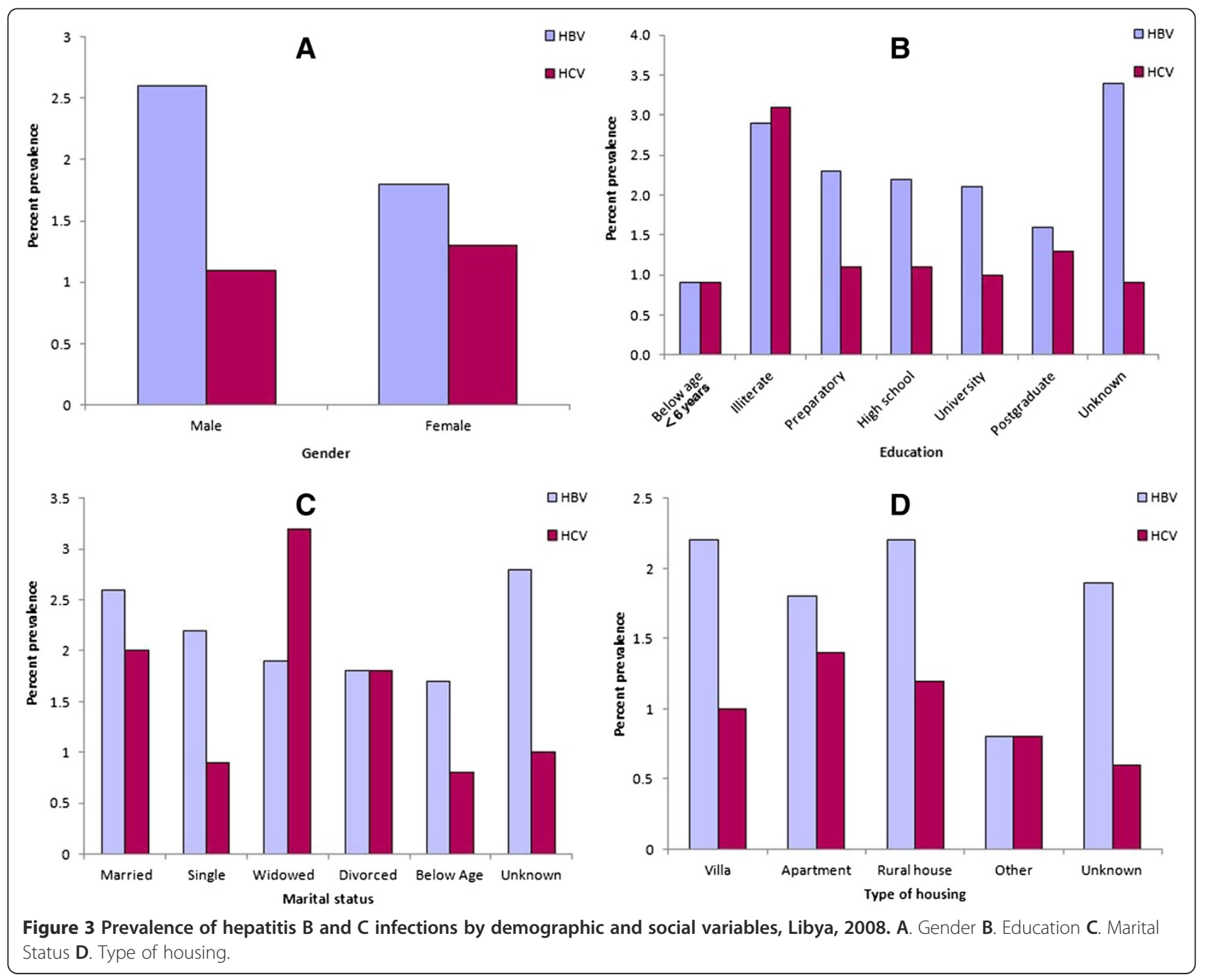


We also analysed the influence of risk factors, such as hospital admission, surgical operation, blood transfusion, intravenous drug use, and sexual behaviour, on the prevalence of hepatitis B and hepatitis C (Figure 4). Hepatitis B virus was most prevalent among those with previous surgical operations $(2.4 \%)$ or history of hospital admission (2.4\%), followed by blood transfusion (2.1\%) and promiscuous sexual behaviour (1.6\%). Hepatitis $C$ was most prevalent among intravenous drug users (7.4\%) and less prevalent but still substantial in those undergoing blood transfusion (2.7\%), surgical operation (2.3\%) or hospital admission (1.9\%).

Table 3 shows the distribution of the estimated seroprevalence of HBV and HCV according to demographic characteristics. There were minimal differences in the estimated number of cases between males and females for $\mathrm{HCV}$, but more than $60 \%$ of the estimated number of HBsAg positive individuals were males. Over $50 \%$ of them were below 30 years old, and about $40 \%$ of HCV cases were also below that age. In terms of educational level, the highest prevalence rate of infection was among illiterates for both viruses (weighted prevalence 2.6\% for $\mathrm{HBsAg}$, representing $12.3 \%$ of all estimated cases, and $3.0 \%$ for $\mathrm{HCV}$, representing $21.8 \%$ of all estimated cases).

\section{Discussion}

The few studies on the prevalence of hepatitis B and C viruses in Libya examined specific population groups, such as parturient women and their newborns [26], healthcare workers, blood donors, transfusion patients [13] and hemodialysis patients [27], or other issues such as prevalence of genotypes [14]. However, none of these studies lend themselves to extrapolation to the general population, and our study, the first of its kind in Libya and the largest in Africa, was done to provide a basis for prioritising public health measures in Libya.

In the European Mediterranean countries, the overall prevalence of HBV ranges between $2.5 \%$ and $3.5 \%$ [28,29]. In contrast, North Africa is overall an area of relatively high HBV endemicity. Tunisia, Algeria and Morocco fall in the intermediate category, with current infection rates of about 7\% [30]. But Egypt is classified among the highest endemicity countries, along with Sudan, Chad and Niger, all of which neighbour Libya [31,32]. The lower prevalence rate of HBV we observed (2.2\%) classifies Libya in the lower part of the low-intermediate endemicity class (2-7\% category). This lower rate could be due to the better socioeconomic conditions and the early efforts by the National Prevention Program of Infectious Diseases in Libya. Vaccination against HBV infection has been strongly encouraged and offered free of charge in Libya since 1989, and in 1991 it became compulsory for infants 3 months of age and children 12 years of age.

Hepatitis $\mathrm{C}$ is an emerging problem among the Mediterranean countries, where the estimated prevalence ranges from $1.0-2.6 \%$, and isolated areas in Italy and Greece have rates of $7-20 \%$ among the general adult population [33,34]. A similar picture was also found in Tunisia and Morocco, where the rates ranged from 1.7 to $2.9 \%$, with higher rates in some regions $[35,36]$. Hepatitis $\mathrm{C}$ virus screening and surveillance is minimal at the national level in these countries. In Libya, a study

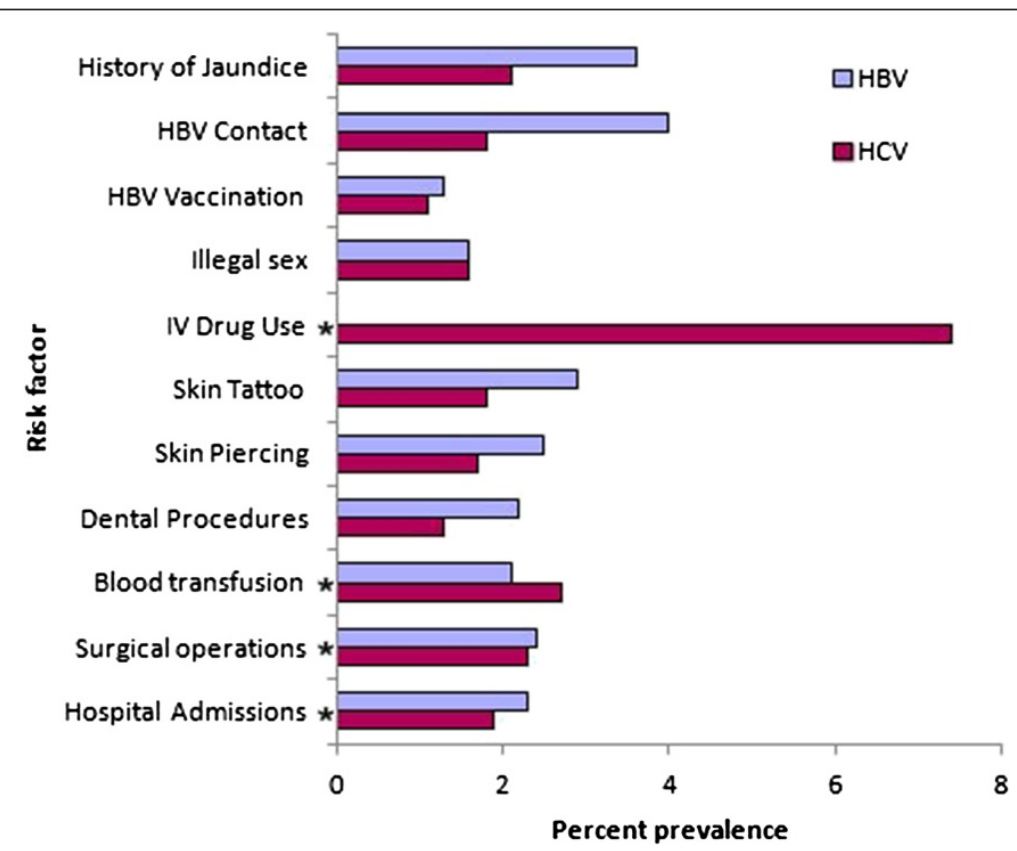

Figure 4 Prevalence of hepatitis B and C infections by risk factors, Libya, 2008 *Statistically significant at 0.05 . 
Table 3 Number of persons chronically infected by HBV and of anti-HCV positive individuals in Libya according to age, socio-demographic factors and risk factors

\begin{tabular}{|c|c|c|c|c|}
\hline & \multicolumn{2}{|c|}{$\begin{array}{l}\text { Nationwide estimated } \\
\text { number of HBsAg } \\
\text { positive persons }\end{array}$} & \multicolumn{2}{|c|}{$\begin{array}{l}\text { Nationwide estimated } \\
\text { number of anti-HCV } \\
\text { positive persons }\end{array}$} \\
\hline & $n$ & $\%$ & $n$ & $\%$ \\
\hline Total & 107,848 & 100 & 68,275 & 100.0 \\
\hline \multicolumn{5}{|l|}{ Gender } \\
\hline Females & 42,297 & 39.2 & 34,845 & 51.0 \\
\hline Males & 65,551 & 60.8 & 33,430 & 49.0 \\
\hline \multicolumn{5}{|l|}{ Age groups } \\
\hline$\leq 5$ & 4,861 & 4.5 & 4,699 & 6.9 \\
\hline $6-10$ & 4,110 & 3.8 & 3,881 & 5.7 \\
\hline $11-20$ & 26,148 & 24.2 & 8,889 & 13.0 \\
\hline $21-30$ & 26,153 & 24.2 & 10,147 & 14.9 \\
\hline $31-40$ & 20,139 & 18.7 & 13,966 & 20.5 \\
\hline $41-50$ & 11,436 & 10.6 & 9,738 & 14.3 \\
\hline $51-60$ & 6,856 & 6.4 & 6,633 & 9.7 \\
\hline $61-70$ & 3,613 & 3.4 & 6,415 & 9.4 \\
\hline$\geq 71$ & 4,532 & 4.2 & 3,907 & 5.7 \\
\hline \multicolumn{5}{|l|}{ Education } \\
\hline Below school age & 4,957 & 4.6 & 5,235 & 7.7 \\
\hline Illiterate & 13,318 & 12.3 & 14,850 & 21.8 \\
\hline Preparatory & 34,927 & 32.4 & 20,685 & 30.3 \\
\hline High school & 34,389 & 31.9 & 17,214 & 25.2 \\
\hline University & 16,118 & 14.9 & 7,544 & 11.0 \\
\hline Post graduate & 1,769 & 1.6 & 981 & 1.4 \\
\hline Unknown & 2,370 & 2.2 & 1,766 & 2.6 \\
\hline \multicolumn{5}{|l|}{ Marital status } \\
\hline Married & 39,844 & 36.9 & 32,605 & 47.8 \\
\hline Single & 42,551 & 39.5 & 17,845 & 26.1 \\
\hline Widowed & 1,425 & 1.3 & 3,403 & 5.0 \\
\hline Divorced & 913 & 0.8 & 470 & 0.7 \\
\hline Below age & 21,434 & 19.9 & 12,828 & 18.8 \\
\hline Unknown & 1,681 & 1.6 & 1,124 & 1.6 \\
\hline \multicolumn{5}{|l|}{ Type of dwelling } \\
\hline Villa & 13,545 & 12.6 & 6,944 & 10.2 \\
\hline Apartment & 10,491 & 9.7 & 10,480 & 15.3 \\
\hline Rural house & 80,646 & 74.8 & 49,398 & 72.4 \\
\hline Other & 118 & 0.1 & 104 & 0.2 \\
\hline Unknown & 3,048 & 2.8 & 1,349 & 2.0 \\
\hline
\end{tabular}

conducted between 1991 and 2001 indicated that the prevalence of $\mathrm{HCV}$ ranged from $1.2 \%$ to $1.6 \%$ among blood donors and healthy individuals but was much higher (20.5\%) among hospital personnel [13]. The 1.2\% rate we observed in our country-wide study classifies
Libya as a low endemicity country. Libya has made screening mandatory for all blood donors, pregnant women, and patients at high risk of having surgery, and has introduced a national registry system covering all positive individuals.

We were not surprised by the substantial regional variation in prevalence rate in Libya. Such variation has also been reported in other Mediterranean countries, such as Italy, Greece and Spain [37-39]. The variation observed in Libya is probably related to different factors, including socioeconomic conditions, but one particular observation is noteworthy. The prevalence of $\mathrm{HCV}$ was highest in the southern region of Fezzan $(2.08 \%)$ and the eastern region of Albatnan (1.77\%). The high prevalence in the southern region could be related to its proximity to subSaharan countries and the hosting of many African immigrants. Likewise, the eastern region of Albatnan borders Egypt, which has the highest prevalence rate of $\mathrm{HCV}$ in the world [40,41], and from where many workers, both legitimate and illegal, come to Libya.

In Libya, the prevalence of HBV was low in children $<10$ years of age $(0.8 \%)$, and in the other age groups it ranged from 2.0 to $2.9 \%$. In most other African countries the prevalence is high among infants and increases rapidly until the age of 30 years, and it rises even higher among those over forty years old $[5,6,42]$. The lower rate in the Libyan population could be due to the compulsory children vaccination program, which was introduced earlier in Libya than in other African countries.

The overall prevalence of HCV in our study was not significantly different between females and males, and it increased gradually after the age of 30 years. This is in agreement with previous studies carried out in Libya, which showed a peak in the prevalence of $\mathrm{HCV}$ among those 46-55 years old [13]. Other studies, particularly from North America, also showed the highest prevalence in the 30-49 year age group in all racial groups [43,44].

We also analysed the risk factors associated with HBV and $\mathrm{HCV}$ infections. The influence of risk factors on the prevalence rate was evident for $\mathrm{HCV}$. The prevalence rate among those with risk factors ranged from 1.9 to $7.4 \%$, whereas among those without risk factors it was $1.3 \%(p<0.025)$. The most prominent risk factor was intravenous drug use, with $7.4 \%$ of intravenous drug users testing positive for $\mathrm{HCV}$. In this context, it is important to note that active drug users are less likely to participate in health surveys, and the actual overall prevalence rate is likely higher than the observed rate $[45,46]$. A recent study on $\sim 1200$ Libyan patients chronically infected with HCV correlated genotypes with risk factors. That study indicated that recent drug use was significantly linked to emergence of new genotypes, lending further credence to the role of intravenous drug use in $\mathrm{HCV}$ transmission in Libya [13]. Accordingly, we expect that 
the prevalence of $\mathrm{HCV}$ may increase in Libya because there is consensus that $\mathrm{HCV}$-infected populations are heavily weighted towards intravenous drug use worldwide [47-49].

Our findings show that the prevalence rates of HBV and $\mathrm{HCV}$ in Libya are relatively low, and this could be an indicator of the success of the national efforts to control these infections. However, we only assessed a marker of the prevalence of HBV chronic infection (HBsAg), which represents the reservoir of infection and of future complications (cirrhosis and liver cancer). We did not estimate the proportion of those who had ever been infected in Libya, which can be estimated by testing for serum anti-HBc antibodies. Moreover, the higher rates in regions bordering high endemicity countries and the poorly controlled state of these borders can lead to an increase in prevalence, especially during this time when the country as whole is experiencing many difficulties. Continuous surveillance and maintenance of the national program for combating hepatitis are essential, and further studies are needed, particularly on co-infection with HIV, which is a problem in this region. Our findings would be useful for making estimates and projections about the overall disease burden, including the complications of hepatitis infection, such as cirrhosis, liver failure, and hepatocellular carcinoma [50]. Recently, El-Bouzedi [51] constructed a mathematical model using published epidemiological data on viral hepatitis to estimate the future consequences of hepatitis infection in Libya. Such modelling will inform health policy, resource allocation and healthcare delivery and may improve the management of patients with viral hepatitis.

\section{Additional files}

Additional file 1: Table S1. HBV, HCV and HIV questionnaire form used to collect the data from Libyan populations.

Additional file 2: Table S2. Sero-prevalence of $\mathrm{HBsAg}$ and anti-HCV antibodies among Libyans according to demographic characteristics and risk exposures.

\section{Competing interests}

The authors state that they have no competing interests.

\section{Authors' contributions}

MD designed the study, extracted the data, and drafted and finalised the manuscript. AE analyzed the data and contributed to the drafting of the data. Both authors read and approved the final manuscript.

\section{Acknowledgement}

We are deeply grateful to the Libyan Study Group of Hepatitis \& HIV and the National Centre for Disease Prevention for their advice and help in this survey. Special thanks go to Dr. Amin Bredan, Inflammation Research Centre, VIB \& Ghent University, Belgium, for his professional contribution in reading, correcting and editing the manuscript.

\section{Author details}

'Department of Medical Microbiology, Faculty of Medicine, Tripoli, Libya. 2Department of Laboratory Medicine, Faculty of Biotechnology, Tripoli, Libya. ${ }^{3}$ Professor of Clinical Microbiology \& Microbial Epidemiology, Acting
Physician of Internal Medicine, Scientific Coordinator of Libyan National Surveillance Studies of Viral hepatitis \& HIV, Tripoli, Libya.

Received: 10 June 2013 Accepted: 2 January 2014

Published: 9 January 2014

\section{References}

1. Te HS, Jensen DM: Epidemiology of hepatitis B and C viruses: a global overview. Clin Liver Dis 2010, 14(1):1-21. vii.

2. Parry J: At last a global response to viral hepatitis. Bull World Health Organ 2010, 88:801-802.

3. Daw M, Dau A: Hepatitis C in Arab world: a state of cencern. Scientific World Journal 2012, 2012:719494.

4. Lavanchy D: Hepatitis B virus epidemiology, disease burden, treatment, and current and emerging prevention and control measures. J Viral Hepat 2004, 11(2):97-107.

5. Rey-Cuille MA, Seck A, Njouom R, Chartier L, Sow HD M, Ka AS, Njankouo M, Rousset D, Giles-Vernick T, et al: Low immune response to hepatitis B vaccine among children in Dakar, Senegal. PLoS One 2012, 7(5):e38153.

6. Abdel-Hady M, Kelly D: Chronic hepatitis B in children and adolescents: epidemiology and management. Paediatr Drugs 2013, 15(4):311-317.

7. Daw MA, Siala IM, Warfalli MM, Muftah MI: Seroepidemiology of hepatitis B virus markers among hospital health care workers. Analysis of certain potential risk factors. Saudi Med J 2000, 21(12):1157-1160.

8. Jafari N, Farajzadegan Z, Ataei B: Surveillance system for hepatitis C infection: a practical approach. Int J Prev Med 2012, 3(Suppl 1):S48-57.

9. Miller ER, McNally S, Wallace J, Schlichthorst M: The ongoing impacts of hepatitis c-a systematic narrative review of the literature. BMC Public Health 2012, 12:672.

10. Muhlberger N, Schwarzer R, Lettmeier B, Sroczynski G, Zeuzem S, Siebert U: HCV-related burden of disease in Europe: a systematic assessment of incidence, prevalence, morbidity, and mortality. BMC Public Health 2009, 9:34

11. WHO: Global surveillance and control of hepatitis C. Report of a WHO Consultation organized in collaboration with the Viral Hepatitis Prevention Board, Antwerp, Belgium. J Viral Hepat 1999, 6(1):35-47.

12. Abdelwahab SF, Hashem M, Galal I, Sobhy M, Abdel-Ghaffar TS, Galal G, Mikhail N, El-Kamary SS, Waked I, Strickland GT: Incidence of hepatitis C virus infection among Egyptian healthcare workers at high risk of infection. J Clin Virol 2013, 57(1):24-28.

13. Daw MA, Elkaber MA, Drah AM, Werfalli MM, Mihat AA, Siala IM: Prevalence of hepatitis $C$ virus antibodies among different populations of relative and attributable risk. Saudi Med J 2002, 23(11):1356-1360.

14. Elasifer HA, Agnnyia YM, Al-Alagi BA, Daw MA: Epidemiological manifestations of hepatitis $C$ virus genotypes and its association with potential risk factors among Libyan patients. Virol J 2010, 7:317.

15. Kershenobich D, Razavi HA, Cooper CL, Alberti A, Dusheiko GM, Pol S, Zuckerman E, Koike K, Han KH, Wallace CM, et al: Applying a system approach to forecast the total hepatitis $C$ virus-infected population size: model validation using US data. Liver Int 2011, 31(Suppl 2):4-17.

16. Remis R: Final Report. Community Acquired Infections Division, Centre for Communicable Diseases and Infection Control. Public Health Agency of Canada 2009.

17. Daw MA, Dau AA, Agnan MM: Influence of healthcare-associated factors on the efficacy of hepatitis C therapy. Scientific World Journal 2012, 2012:580216.

18. Heisey-Grove DM, Church DR, Haney GA, Demaria A Jr: Enhancing surveillance for hepatitis $C$ through public health informatics. Public Health Rep 2011, 126(1):13-18.

19. Hamdy A: ICT in Education in Libya. Libya Country Report: Survey of ICT and Education in Africa; 2007. www.infodev.org.

20. El Oakley RM, Ghrew MH, Aboutwerat AA, Alageli NA, Neami KA, Kerwat RM Elfituri AA, Ziglam HM, Saifenasser AM, Bahron AM, et al: Consultation on the Libyan health systems: towards patient-centred services. Libyan J Med 2013, 8

21. Clark N: Education in Libya. World Eduction News and Reviews: World Education Services; 2004. http://www.wes.org/ewenr/PF/04Jul/PFPractical.htm.

22. El Taguri A, Elkhammas E, Bakoush O, Ashammakhi N, Baccoush M, Betilmal I: Libyan National Health Services The Need to Move to Managementby-Objectives. Libyan J Med 2008, 3(2):113-121.

23. Bagasra O, Alsayari M, Bullard-Dillard R, Daw MA: The Libyan HIV Outbreak How do we find the truth? Libyan J Med 2007, 2(2):57-62. 
24. Daw M, Elkhammas E: Libyan medical education; time to move forward. Libyan J Med 2008, 3(1):1-3.

25. World Medical Association Ethics Unit:; 2009. http://www.wma.net/en/ 30publications/10policies/b3/index.html.

26. Daw MA, Elwarvelli MM, Siala IM, Backush M, Elussabie H: Prevalence of HBsAg among Libyan populations: a comparative study. Annals of Saudi Medicine 2001, 21:130-132.

27. Alashek WA, Christopher W, Mclntyre CW, Taal MW: Hepatitis B and C infection in haemodialysis patients in Libya: prevalence, incidence and risk factors. BMC Infectious Diseases 2012, 12:265. doi:10.1186/1471-2334-12-265.

28. Karatapanis S, Skorda L, Marinopoulos S, Papastergiou V, Drogosi M, Lisgos $P$, Antsaklis $A$ : Higher rates of chronic hepatitis B infection and low vaccination-induced protection rates among parturients escaping $\mathrm{HBs} A g$ prenatal testing in Greece: a 2-year prospective study. Eur J Gastroenterol Hepatol 2012, 24(8):878-883.

29. Romano L, Velati C, Cambie G, Fomiatti L, Galli C, Zanetti AR: Hepatitis B virus infection among first-time blood donors in Italy: prevalence and correlates between serological patterns and occult infection. Blood Transfus 2013, 11(2):281-288.

30. Ezzikouri S, Pineau P, Benjelloun S: Hepatitis B virus in the Maghreb region: from epidemiology to prospective research. Liver Int 2013, 33(6):811-819.

31. Barth RE, Huijgen Q, Taljaard J, Hoepelman Al: Hepatitis B/C and HIV in sub-Saharan Africa: an association between highly prevalent infectious diseases. A systematic review and meta-analysis. Int J Infect Dis 2010, 14(12):e1024-1031.

32. Wasfi O, Sadek N: Prevalence of hepatitis B surface antigen and hepatitis $C$ virus antibodies among blood donors in Alexandria. Egypt. East Mediterr Health J 2011, 17(3):238-242.

33. Goritsas C, Plerou I, Agaliotis S, Spinthaki R, Mimidis K, Velissaris D, Lazarou N, Labropoulou-Karatza C: HCV infection in the general population of a Greek island: prevalence and risk factors. Hepatogastroenterology 2000, 47(33):782-785.

34. Raffaele A, Valenti M, lovenitti M, Matani A, Bruno ML, Altobelli E, D'Alessandro A, Barnabei R, Leonardis B, Taglieri G: High prevalence of HCV infection among the general population in a rural area of central Italy. Eur J Epidemiol 2001, 17(1):41-46.

35. Benouda A, Boujdiya Z, Ahid S, Abouqal R, Adnaoui M: [Prevalence of hepatitis $C$ virus infection in Morocco and serological tests assessment of detection for the viremia prediction]. Pathol Biol (Paris) 2009, 57(5):368-372.

36. Mejri S, Salah AB, Triki H, Alaya NB, Djebbi A, Dellagi K: Contrasting patterns of hepatitis $C$ virus infection in two regions from Tunisia. J Med Virol 2005, 76(2):185-193

37. Cozzolongo R, Osella AR, Elba S, Petruzzi J, Buongiorno G, Giannuzzi V, Leone G, Bonfiglio C, Lanzilotta E, Manghisi OG, et al: Epidemiology of HCV infection in the general population: a survey in a southern Italian town. Am J Gastroenterol 2009, 104(11):2740-2746.

38. Garcia-Fulgueiras A, Tormo MJ, Rodriguez T, Perez-Flores D, Chirlaque D, Navarro C: Prevalence of hepatitis B and C markers in the south-east of Spain: an unlinked community-based serosurvey of 2,203 adults. Scand J Infect Dis 1996, 28(1):17-20.

39. Gogos CA, Fouka KP, Nikiforidis G, Avgeridis K, Sakellaropoulos G, Bassaris H, Maniatis A, Skoutelis A: Prevalence of hepatitis B and C virus infection in the general population and selected groups in South-Western Greece. Eur J Epidemiol 2003, 18(6):551-557.

40. Breban R, Doss W, Esmat G, Elsayed M, Hellard M, Ayscue P, Albert M, Fontanet A, Mohamed MK: Towards realistic estimates of HCV incidence in Egypt. J Viral Hepat 2013, 20(4):294-296.

41. Guerra J, Garenne M, Mohamed MK, Fontanet A: HCV burden of infection in Egypt: results from a nationwide survey. J Viral Hepat 2012, 19(8):560-567.

42. Triki H, Said N, Ben Salah A, Arrouji A, Ben Ahmed F, Bouguerra A, Hmida S, Dhahri $R$, Dellagi K: Seroepidemiology of hepatitis $B, C$ and delta viruses in Tunisia. Trans R Soc Trop Med Hyg 1997, 91(1):11-14.

43. Kim WR: The burden of hepatitis C in the United States. Hepatology 2002, 36(5 Suppl 1):S30-34

44. Uhanova J, Tate RB, Tataryn DJ, Minuk GY: A population-based study of the epidemiology of hepatitis $C$ in a North American population. $J$ Hepatol 2012, 57(4):736-742.

45. Havens JR, Lofwall MR, Frost SD, Oser CB, Leukefeld CG, Crosby RA: Individual and network factors associated with prevalent hepatitis $C$ infection among rural Appalachian injection drug users. Am J Public Health 2012, 103(1):e44-52
46. Wong NS, Chan PC, Lee SS, Lee SL, Lee CK: A multilevel approach for assessing the variability of hepatitis $C$ prevalence in injection drug users by their gathering places. Int J Infect Dis 2013, 17(3):e193-198.

47. McDonald SA, Hutchinson SJ, Schnier C, McLeod A, Goldberg DJ: Estimating the number of injecting drug users in Scotland's HCVdiagnosed population using capture-recapture methods. Epidemiol Infect 2014, 142(1):200-207.

48. Sood A, Sarin SK, Midha V, Hissar S, Sood N, Bansal P, Bansal M: Prevalence of hepatitis $C$ virus in a selected geographical area of northern India: a population based survey. Indian J Gastroenterol 2012, 31(5):232-236.

49. Szabo SM, Bibby M, Yuan Y, Donato BM, Jimenez-Mendez R, CastanedaHernandez G, Rodriguez-Torres M, Levy AR: The epidemiologic burden of hepatitis C virus infection in Latin America. Ann Hepatol 2012, 11(5):623-635.

50. Hagan LM, Schinazi RF: Best strategies for global HCV eradication. Liver Int 2013, 33(Suppl 1):68-79.

51. El-Bouzedi A: Investigation and modeling the epidemiology of hepatitis C virus in Libya, Ph D Thesis. United Kingdom: University of Glamorgan, Faculty of Advanced Technology; 2012.

doi:10.1186/1471-2334-14-17

Cite this article as: Daw and El-Bouzedi: Prevalence of hepatitis B and hepatitis $C$ infection in Libya: results from a national population based survey. BMC Infectious Diseases 2014 14:17

\section{Submit your next manuscript to BioMed Central and take full advantage of:}

- Convenient online submission

- Thorough peer review

- No space constraints or color figure charges

- Immediate publication on acceptance

- Inclusion in PubMed, CAS, Scopus and Google Scholar

- Research which is freely available for redistribution

Submit your manuscript at www.biomedcentral.com/submit
C) Biomed Central 